\title{
Pollinator biodiversity and floral resource use in Ecballium elaterium (Cucurbitaceae), a Mediterranean endemic
}

\author{
Richard W. RUST ${ }^{\mathrm{a} *}$, Bernard E. VAISSIÈRE ${ }^{\mathrm{b}}$, Paul WESTRICH ${ }^{\mathrm{c}}$ \\ a Department of Biology, University of Nevada, Reno, Nevada, USA \\ b Laboratoire de Pollinisation Entomophile, INRA UMR 406 Écologie des Invertébrés, Avignon, France \\ ${ }^{\mathrm{c}}$ Natural History Museum Stuttgart (SMNS), Roesenstein 1, 70191, Stuttgart, Germany
}

(Received 25 February 2002; revised 18 April 2002; accepted 20 May 2002)

\begin{abstract}
Pollinator biodiversity on Ecballium elaterium (L.) A. Richard was studied for 2 years at 2 sites in southern France. Six families, 15 genera, and 43 species of bees were collected from the flowers, and 33 bee species carried Ecballium pollen in their scopae. The numerically dominant species were Lasioglossum malachurum (Kirby), the honey bee, Apis mellifera L., and Ceratina cyanea (Kirby). Few pollinators were observed in 1997 due to a drought. In 1996, mean forager density was slightly over one bee per 100 flowers throughout the flowering period. Most visitors (98\%) were female bees which foraged for both pollen and nectar. Most visits $(97 \%)$ were to staminate flowers and visitation to pistillate flowers was by deceit since these are nectarless. Behavior of nectar foragers on staminate flowers differed according to body size. Large bees foraged for nectar mostly in the afternoon after nectar sugar concentrations reached high values while smaller bees foraged for nectar throughout the day.
\end{abstract}

Ecballium / bee / nectar / pollen / foraging / deceit pollination

\section{INTRODUCTION}

The importance of pollinator diversity in different ecosystems has become an issue of interest in the past few years (Buchmann and Nabham, 1996; Kevan et al., 1997; Frankie et al., 1997; Allen et al., 1998; Kevan, 1999; Council for Agriculture Science and Technology, 1999). These works have stressed the general lack of detailed information on ecosystem pollinator biodiversity, the importance of pollination in both natural and crop ecosystems and the necessity to know and preserve the biodiversity of pollinators in any ecosystem management planning.

Recently, there has been an increase in pollinator diversity studies in the Mediterranean region on both individual plant species (Herrera, 1989; Bosch, 1992; Affre and Thompson, 1997; Talavera et al., 2001) and regional assemblages of plants (Herrera C.M., 1987, 1988, 1992, 1993, 1996; Herrera J., 1988; Petanidou and Vokou, 1990; Dafni et al., 1990; Petanidou and Smets, 1995; PottsSimon et al., 2001). These reports have focused on both the natural history of pollinator systems and analyses of regional floras and the relationship between pollination and floral adaptations.

The purpose of our research is to present new information on the diversity of anthophilous foragers, their resource utilization and seasonal and daily visitation patterns to Ecballium elaterium (L.) A. Richard (Cucurbitaceae) in the

\footnotetext{
* Correspondence and reprints

E-mail: rwrust@unr.edu
} 
Mediterranean region. Ecballium elaterium (spitting cucumber, squirting cucumber) is a monotypic species of cucurbit restricted to the Mediterranean Basin. It is a procumbent herbaceous perennial that is monoecious through most of its range (Tutin et al., 1968) but with dioecious individuals in northern Africa and southern Spain and Portugal (Costich and Meagher, 1992). It occurs in small populations (50-100 individuals) found in sandy or stony ground near the sea and as a ruderal in disturbed habitats like roadsides, canal embankments, garbage dumps, abandoned lots, and near cultivation. Flowering begins in April and may last until December with peak flowering between May and August (Fhan and Shimony, 2001). Seed dispersal from the fruit is by explosive dehiscence (McLean and IvimelyCook, 1956). Cells in the walls of the fruit are under compression from high osmotic pressure. They expand very rapidly when the mature fruit is loosened from the connection with the pedicel and the seeds are shot out of the basal opening (McLean and Ivimely-Cook, 1956). Ecballium is of interest today because of its historical and renewed use in Mediterranean countries as a medicinal plant (Jodral et al., 1990), its anti-insect compounds (PascualVillalobos and Robledo, 1999) and also as a reservoir for viruses that infect cucurbitaceous crops (Ben et al., 1996). It is also of interest to pollination biologists because its pistillate flowers offer neither nectar nor pollen and are pollinated solely by deceit.

\section{MATERIALS AND METHODS}

\subsection{Study sites}

The density of Ecballium flowers was measured biweekly from June through September in four (1996) and five (1997) populations $4 \mathrm{~km}$ northwest of Port-Saint-Louis-du-Rhône (PSL), Bouches-duRhône, France (N43⒉18' - E4 48.19' and 5 m elevation) and in one population in June and August (1996) at Caumont-sur-Durance (CSD), Vaucluse, France (N43 ${ }^{\circ} 53.44^{\prime}-\mathrm{E} 4^{\circ} 56.49^{\prime}$ and $74 \mathrm{~m}$ elevation). PSL site was considered a natural site in the Camargue area of the Rhône River delta (Harant and Jarry, 1963; Molinier and Devaux, 1978; Martin, 1997). The study area was a flat, salt marsh region approximately $5 \mathrm{~m}$ above sea level. The vegetation at the site consisted of native species. Dom- inant tall species were scattered tamarix, Tamarix gallica L., and Russian olive, Elaegnus angustifolius L., trees and patches of the grasses (canne de Provence) Arundo donax L. and phragmites, Phragmites communis Trin. Patches and individual plants of the thistles, Cardon spp., Onopordum nervosum, Cirsium spp., Scolymus hispanicus L., Inula viscosa, the rush, Juncus aculeatus, and the saltbush, Atriplex halimus L., formed the herbaceous "shrub" component of the vegetation. Other common flowering herbaceous species throughout the area were Glaucium flavum Crantz, Limonium minutum (L. Chaz.), L. vulgare Miller, Heliotropum europaeum L., Blackstonia perfoliata (L.) Hudson and Ecballium elaterium. The CSD site was located in a disturbed area adjacent to the municipal garbage dump. The CSD site was destroyed by land development activities in 1997.

\subsection{Forager density and behavior}

Foragers were counted hourly in 100 staminate and/or pistillate Ecballium flowers per population during the weekly sampling periods beginning in July 1996. In 1997, there were too few foragers to measure the density per 100 flowers throughout any part of the blooming period due to the reduced flowering caused by the limited precipitation throughout the growing season. In 1996, the mean monthly precipitation at PSL for the eight months of January through August was 65 $\pm 69 \mathrm{~mm}$ (high 209.5 in January, low 4.3 in May) and in 1997 the average was only $30 \pm 38 \mathrm{~mm}$ (high 91.5 in June and low 0.0 in March with February, April, May and July with less than $15 \mathrm{~mm}$ ) (Météo-France 2001 - Données Climatologiques Départementales, Bouches du Rhône, Port-Saint-Louis-du-Rhône).

\subsection{Forager collections and resource utilization}

Visitors to both staminate and pistillate Ecballium flowers were collected throughout the day from sunrise to sunset. Individuals were stored in glass vials with time and date of collection, chilled on ice and examined for pollen and sampled for nectar. All were preserved for identification. The presence of Ecballium pollen was confirmed by microscopic examination. Nomenclature is based on Westrich (1989) for pollinator, oligolecty and polylecty. Flower handling time and travel time between Ecballium flowers were measured in 1996 by recording individual visitations with a hand-held tape recorder and transcribing tape time to seconds. A bee observed foraging in a flower was recorded from the time it left the flower until it flew from the patch or was lost from sight. Individual bee foraging trips to three or more flowers were used in the analysis. 


\subsection{Nectar production and nectar foraging}

Nectar production was measured on bagged pistillate and staminate flowers at both PSL and CSD sites. Flowers were bagged at dawn before insect foraging and sampled hourly throughout the day. Nectar from bagged flowers was extracted with $10-\mu \mathrm{L}$ micropipets and the volume was calculated from the length of the column in the micropipet. The sugar concentration in total dissolved solids was measured with a portable refractometer (Bellingham and Stanley, Tunbridge Wells, UK). Flower nectar sugar content was determined using Cruden and Hermann (1983) correction of total dissolved solids. Foraging insects were collected from both staminate and pistillate flowers and individuals were placed in individual vials as described above. Individuals were removed from cold storage and briefly gassed with carbon dioxide and any nectar stored in the crop was collected with $10-\mu \mathrm{L}$ micropipets. If the stored nectar was not visible after the carbon dioxide treatment, the specimen's abdomen was gently squeezed until the crop content was extruded. Volume and total dissolved solids were measured as described for the floral nectar. We followed Vaissière et al. (1996) for identification of forager nectar source. Forager crop content whose concentration was within $\pm 5 \%$ of that of the total dissolved solids of bagged flower nectar at the time of collection was considered Ecballium nectar.

\subsection{Statistical analysis}

Normal-theory statistical analysis was used on continuous variables by applying standard analysis of variance (ANOVA) procedures (Sokal and Rohlf, 1995). Volume of nectar per flower and per forager were analyzed after a log transformation with 1 added to null values (Sokal and Rohlf, 1995). Flower handling time and travel time to next flower were analyzed after a log transformation (Schaffer and Schaffer, 1979; Schaffer et al., 1983). Two-factor ANOVA was used to analyze mean flower handling times and travel times to the next flower among pollinators. Regression analysis was applied to forager flower visitation time in seconds to the time of day in decimal hours (Sokal and Rohlf, 1995). Normality of the seasonal distribution flowers was tested with Kolmogorov-Smirnov (Sokal and Rohlf, 1995). Chi-square analysis was used to compare bee visitation to pistillate flowers to the number of pistillate flowers present in the flower population. The means are given $\pm 1 \mathrm{SD}$ and in all cases the significant probability was computed.

Specimens from this study are deposited at two locations: Laboratoire de Pollinisation Entomophile,
INRA, Avignon, France and R.M. Bohart Museum, University of California, Davis, California, USA. The unidentified specimens of Colletes and duplicates of several bee species are in the Paul Westrich collection in Kusterdingen, Germany.

\section{RESULTS}

\subsection{Flower density}

Mean flower density in the PSL populations in 1996 was $7.5 \pm 8.6$ flowers $/ \mathrm{m}^{2}$ with $5.9 \pm 6.9$ staminate flowers and $1.6 \pm 1.9$ pistillate flowers $/ \mathrm{m}^{2}$ (Fig. 1). Seasonally, staminate and pistillate flowers for 1996 were normally distributed $\left(\mathrm{D}_{\text {male }}=0.281, P=0.2\right.$ and $\mathrm{D}_{\text {female }}=$ $0.235, P=0.5)$. Flower numbers increased seasonally from an early season low of $1.8 \pm 1.4$ flowers $/ \mathrm{m}^{2}$ to a late season high of $14.9 \pm 13.6$ flowers $/ \mathrm{m}^{2}$. In 1997 , mean flower density in the PSL populations was only $2.7 \pm 1.0$ flowers $/ \mathrm{m}^{2}$ with $2.5 \pm 0.9$ staminate flowers and $0.1 \pm 0.1$ pistillate flowers $/ \mathrm{m}^{2}$ (Fig. 1). Staminate and pistillate flowers for 1997 were also normally distributed $\left(\mathrm{D}_{\text {male }}=\right.$ $0.260, P=0.5$ and $\mathrm{D}_{\text {female }}=0.192, P=0.5$ ). Flower numbers decreased seasonally from an early season of 2.4 flowers $/ \mathrm{m}^{2}$ to 1.7 flowers/ $\mathrm{m}^{2}$ late in the season. Seasonal percentage of staminate to pistillate flowers in 1996 was 78.4 to 21.6 and in 1997 was 93.5 to 6.5 .

\subsection{Nectar production}

Bagged pistillate flowers produced no nectar. Nectar production in bagged staminate flowers began after sunrise with a rapid increase between 08:00 to 10:00 GMT and then leveled off. The mean total dissolved solids $(\mathrm{g} / \mathrm{g})$ were significantly different between $\mathrm{PSL}$ and $\mathrm{CSD}(\mathrm{F}=15.2, \mathrm{df}=1,61$, $P \leq 0.0001$; PSL $-0.28 \pm 0.16$ and CSD $0.46 \pm 0.19)$ as was the mean volume of nectar $(\mu \mathrm{L} /$ flower $)(\mathrm{F}=11.2, \mathrm{df}=1,73, P=0.001$; PSL $-0.65 \pm 0.53$ and CSD $-0.31 \pm 0.27)$. However, the mean sugar content was not significantly different (PSL $-0.17 \pm 0.09 \mathrm{~g}$ and CSD $-0.14 \pm 0.13 \mathrm{~g}, P=0.27)$.

\subsection{Foragers}

Six families, 15 genera and 43 species of bees representing 852 individuals were collected from Ecballium flowers (Tab. I). Very few 
Table I. Bee foragers on Ecballium elaterium for 1996 and 1997 in Caumont-sur-Durance and Port-SaintLouis, France $(\mathrm{Y}=$ Ecballium pollen present in scopae of at least one individual, $\mathrm{N}=$ no Ecballium pollen in scopae; $\mathrm{f}=$ female, $\mathrm{m}=$ male).

\begin{tabular}{|c|c|c|c|c|c|c|}
\hline \multirow[b]{2}{*}{ Species } & & \multirow[b]{2}{*}{ Pollen } & \multirow{2}{*}{$\begin{array}{c}\text { Caumont-sur- } \\
\text { Durance } \\
1996\end{array}$} & \multicolumn{2}{|c|}{ Port-Saint-Louis } & \multirow[t]{2}{*}{ Total } \\
\hline & & & & 1996 & 1997 & \\
\hline \multicolumn{7}{|c|}{ Colletidae } \\
\hline Colletes species & $\mathrm{Y}$ & & - & - & $10 \mathrm{f}$ & $10 \mathrm{f}$ \\
\hline Hylaeus confusus Nylander & $\mathrm{N}$ & & - & 1f & $2 f$ & $3 f$ \\
\hline Hylaeus gibbus Saunders & $\mathrm{N}$ & & - & 1f & $5 f$ & $6 f$ \\
\hline \multicolumn{7}{|c|}{ Halictidae } \\
\hline Halictus pollinosus Sich. & $\mathrm{Y}$ & & - & $1 \mathrm{f}$ & - & $1 \mathrm{f}$ \\
\hline Halictus scabiosae (Rossi) & $\mathrm{N}$ & & - & $8 \mathrm{f}$ & - & $8 \mathrm{f}$ \\
\hline Halictus simplex (group) & $\mathrm{Y}$ & & $2 \mathrm{f}$ & $2 \mathrm{f}, 1 \mathrm{~m}$ & $5 f$ & $9 \mathrm{f}, 1 \mathrm{~m}$ \\
\hline Halictus smaragdulus Vachal & $\mathrm{Y}$ & & $4 \mathrm{f}$ & - & - & $4 \mathrm{f}$ \\
\hline Halictus tectus Rad. & $\mathrm{N}$ & & - & 1f & $5 f$ & $6 f$ \\
\hline Lasioglossum calceatum (Scop.) & $\mathrm{Y}$ & & $2 \mathrm{f}$ & - & - & $2 \mathrm{f}$ \\
\hline Lasioglossum discum (Smith) & $\mathrm{Y}$ & & $8 \mathrm{f}$ & $4 \mathrm{f}$ & $36 f$ & $48 \mathrm{f}$ \\
\hline Lasioglossum glabriusculum (Morawitz) & $\mathrm{Y}$ & & $2 f$ & - & - & $2 f$ \\
\hline Lasioglossum griseolum (Morawitz) & $\mathrm{N}$ & & 1f & - & - & 1f \\
\hline Lasioglossum leucozonium (Schrank) & $\mathrm{Y}$ & & 1f & - & - & $1 \mathrm{f}$ \\
\hline Lasioglossum malachurum (Kirby) & $\mathrm{Y}$ & & $113 \mathrm{f}$ & $6 \mathrm{f}$ & $20 \mathrm{f}$ & $139 \mathrm{f}$ \\
\hline Lasioglossum minutissimum (Kirby) & $\mathrm{Y}$ & & - & $2 f$ & $4 f$ & $6 \mathrm{f}$ \\
\hline Lasioglossum morio (Fabricius) & $\mathrm{Y}$ & & $15 \mathrm{f}, 1 \mathrm{~m}$ & - & - & $15 \mathrm{f}, 1 \mathrm{~m}$ \\
\hline Lasioglossum nigripes (Lepeletier) & $\mathrm{N}$ & & - & $1 \mathrm{f}$ & 1f & $2 \mathrm{f}$ \\
\hline Lasioglossum nitidulum (Fabricius) & $\mathrm{Y}$ & & $31 \mathrm{f}$ & - & - & $31 \mathrm{f}$ \\
\hline Lasioglossum punctatissimum (Schenck) & $\mathrm{Y}$ & & $8 f$ & 1f & $3 \mathrm{f}$ & $12 \mathrm{f}$ \\
\hline Lasioglossum soror (Saunders) & $\mathrm{N}$ & & $1 \mathrm{~m}$ & - & - & $1 \mathrm{~m}$ \\
\hline Lasioglossum villosulum (Kirby) & $\mathrm{Y}$ & & - & $4 \mathrm{f}, 1 \mathrm{~m}$ & $7 \mathrm{f}, 1$ & $\mathrm{n} 11 \mathrm{f}, 2 \mathrm{~m}$ \\
\hline Lasioglossum zonulum (Smith) & $\mathrm{Y}$ & & 1f & If & $4 \mathrm{f}$ & $6 \mathrm{f}$ \\
\hline Lasioglossum species & $\mathrm{Y}$ & & $6 f$ & - & 1f & $7 f$ \\
\hline Pseudapis diversipes (Latr.) & $\mathrm{Y}$ & & 1f & $4 \mathrm{f}$ & $8 f$ & $13 \mathrm{f}$ \\
\hline Pseudapis unidentata (Oliv.) & $\mathrm{Y}$ & & - & - & $2 \mathrm{f}$ & $2 \mathrm{f}$ \\
\hline Nomioides variegatus (Oliv.) & $\mathrm{Y}$ & & - & $10 \mathrm{f}, 2 \mathrm{~m}$ & $17 \mathrm{f}, 1$ & n $27 f, 3 m$ \\
\hline \multicolumn{7}{|c|}{ Melittidae } \\
\hline Melitta leporina (Panzer) & $\mathrm{Y}$ & & - & 1f & - & $1 \mathrm{f}$ \\
\hline & & & hilidae & & & \\
\hline Anthidium florentinum (Fab.) & $\mathrm{N}$ & & 1f & - & - & $1 \mathrm{f}$ \\
\hline Anthidium infuscatum Erichson & $\mathrm{Y}$ & & 1f & - & - & 1f \\
\hline Anthidium laterale Latreille & $\mathrm{N}$ & & 1f & - & - & 1f \\
\hline Megachile centuncularis $(\mathrm{L})$. & $\mathrm{Y}$ & & - & $6 f$ & $9 f$ & $15 f$ \\
\hline Megachile deceptoria Perez & $\mathrm{Y}$ & & - & - & $9 \mathrm{f}$ & $9 \mathrm{f}$ \\
\hline Megachile pilidens Alfken & $\mathrm{Y}$ & & - & $4 \mathrm{f}$ & 9f & $13 \mathrm{f}$ \\
\hline Megachile rotundata $(\mathrm{F})$. & $\mathrm{Y}$ & & - & $4 f$ & $6 f$ & $10 \mathrm{f}$ \\
\hline Osmia crenulata (Nylander) & $\mathrm{Y}$ & & 1f & - & - & 1f \\
\hline \multicolumn{7}{|c|}{ Anthophoridae } \\
\hline Anthophora quadrifasciata (Villers) & $\mathrm{Y}$ & & - & $8 \mathrm{f}$ & $10 f$ & $18 \mathrm{f}$ \\
\hline Ceratina cucurbitina (Rossi) & $\mathrm{Y}$ & & $18 \mathrm{f}$ & - & - & $18 \mathrm{f}$ \\
\hline Ceratina cyanea (Kirby) & $\mathrm{Y}$ & & $53 \mathrm{f}$ & $10 \mathrm{f}, 5 \mathrm{~m} 18 \mathrm{f}, 6 \mathrm{~m}$ & & $81 \mathrm{f}, 11 \mathrm{~m}$ \\
\hline Ceratina parvula (Smith) & $\mathrm{N}$ & & $11 \mathrm{f}$ & - & - & $11 \mathrm{f}$ \\
\hline Xylocopa violacea $(\mathrm{L})$. & $\mathrm{Y}$ & & - & $10 \mathrm{f}, 1 \mathrm{~m} 16 \mathrm{f}, 1 \mathrm{~m}$ & & $26 \mathrm{f}, 2 \mathrm{~m}$ \\
\hline \multicolumn{7}{|c|}{ Apidae } \\
\hline Apis mellifera $\mathrm{L}$. & $\mathrm{Y}$ & & $47 f$ & $34 \mathrm{f}$ & $34 f$ & $115 f$ \\
\hline Bombus terrestris L. & $\mathrm{Y}$ & & if & - & - & if \\
\hline Bombus pascuorum (Scop.) & $\mathrm{Y}$ & & - & - & $4 \mathrm{f}$ & $4 \mathrm{f}$ \\
\hline
\end{tabular}



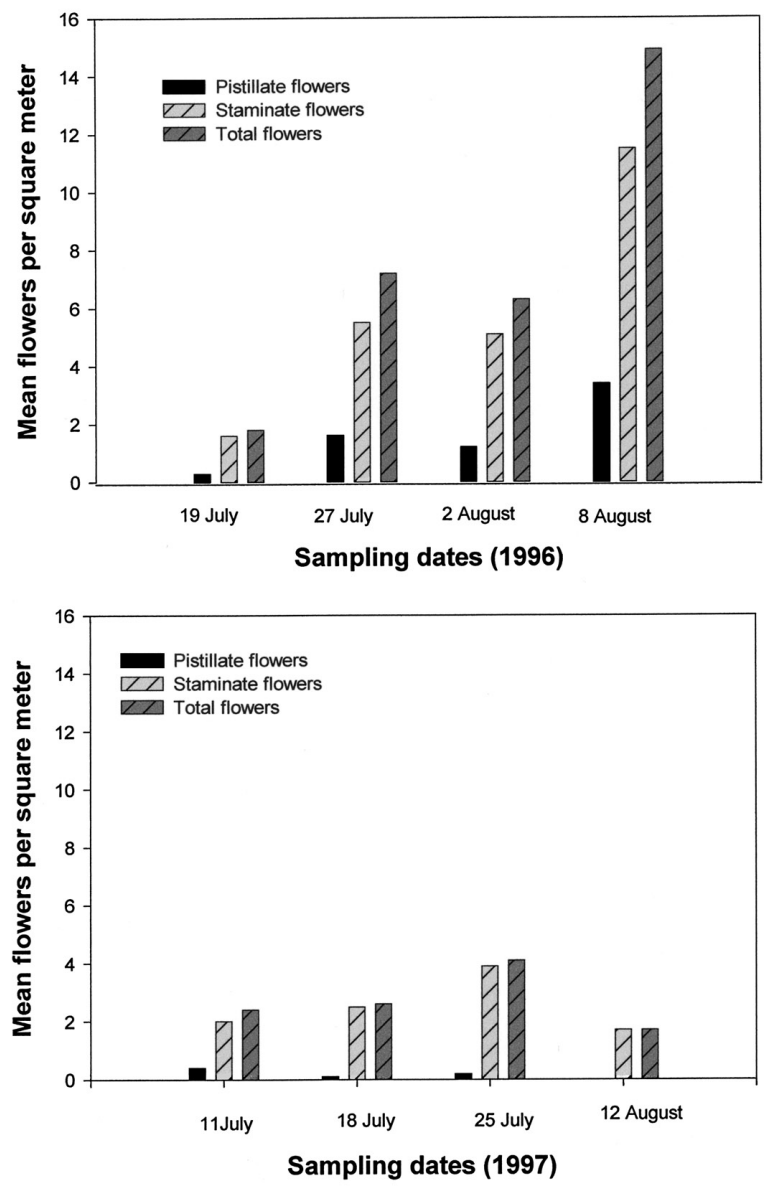

Figure 1. Flower density (mean staminate, pistillate and total flowers) of Ecballium elaterium in four populations near Port-Saint-Louis, France, during the flowering period in 1996 (upper figure) and 1997 (lower figure).

male bees (21) were obtained. Thirty-three of the species carried Ecballium pollen in their scopae and are defined as pollinators. Eleven species were represented by one-individual and four of the one-individual species carried no Ecballium pollen and are considered flower visitors. Ten of the one-individual species were from CSD. Nine species were collected from both sites and all carried Ecballium pollen. Fifteen species were from CSD of which 10 carried Ecballium pollen and 19 species were from PSL of which 13 carried Ecballium pollen. The most commonly collected species was Lasioglossum malachurum (Kirby), followed by the honey bee, Apis mellifera L., and Ceratina cyanea (Kirby). All three were collected from both sites. The majority of foragers identified as pollen foragers by the presence of Ecballium pollen in their scopae or corbiculae are considered polylegs in their for- aging behavior. The most unusual visitor was Melitta leporina (Panzer) (Melittidae), a known oligoleg on Fabaceae (Westrich, 1989). Melitta leporina bees collected both Ecballium pollen and nectar. Also of interest is Pseudapis unidentata (Oliv.) (Halictidae). Our collections are the first for this species in France.

Adult and larval coccinellid beetles, Epilachna chrysomelina F., were collected from male flowers and larvae were seen feeding on the pollen and anthers as well as the leaves. Syrphid flies, most likely species of Eristalis, were seen hovering about male flowers.

\subsection{Forager density}

In 1996, the mean foragers per 100 flowers averaged $1.1 \pm 2.2$ individuals throughout the 

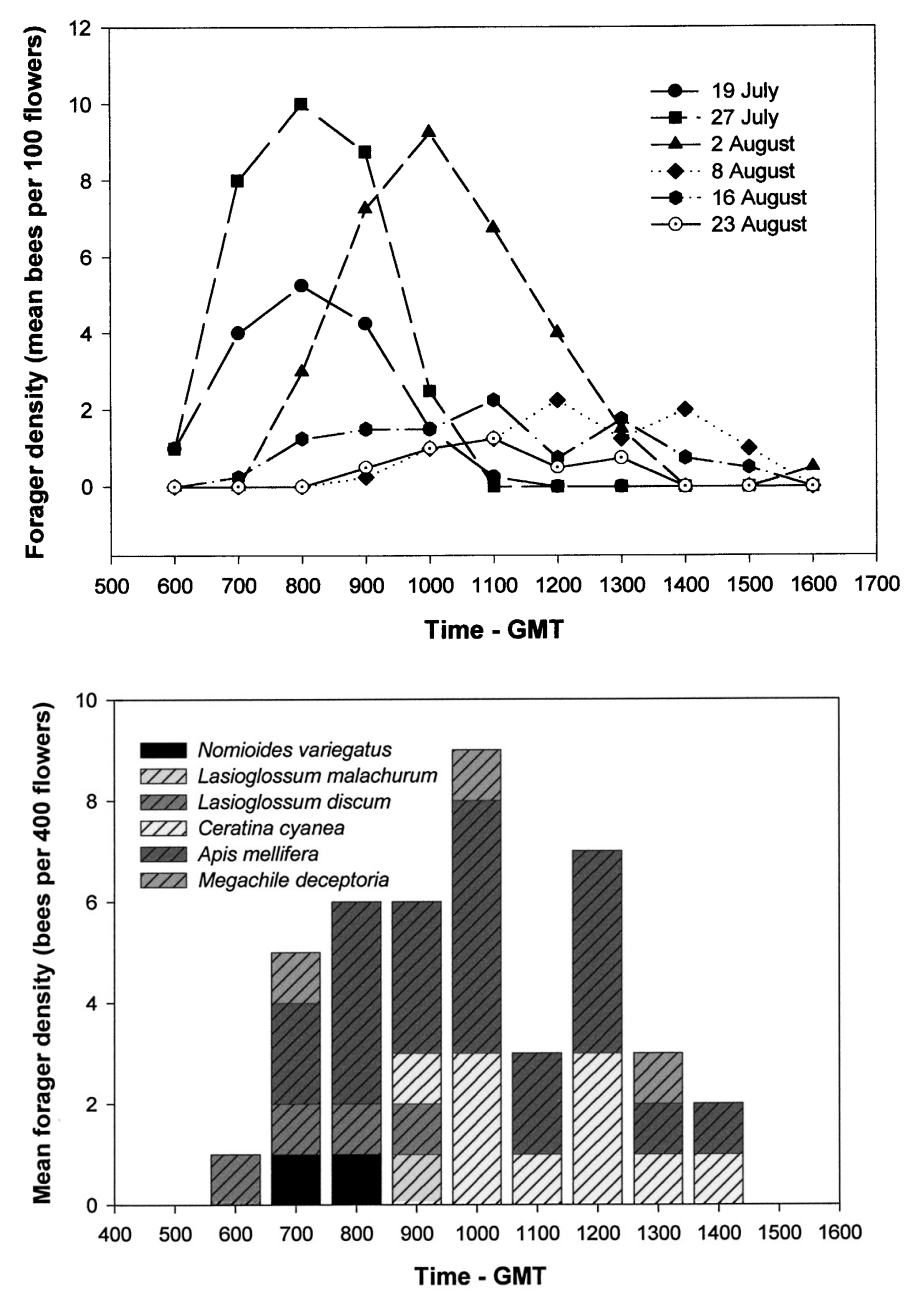

Figure 2. Foraging activity on Ecballium elaterium, staminate and pistillate flowers combined, near Port-Saint-Louis, France, for six sampling periods in 1996.
Figure 3. Foraging activities of 6 bee species on Ecballium elaterium, staminate and pistillate flowers combined, near PortSaint-Louis, France, on 16 August 1996. entire flowering period. The largest number (10) recorded was during the morning hours of 27 July (Fig. 2). However, this high number of foragers was reduced to zero for the rest of the day by a sudden and prolonged rainstorm. The other sample periods showed lower average number of foragers with July 19 and August 2 showing morning peaks and the other dates with fairly even distribution throughout the day (Fig. 2).

The most common foragers showed different diel distribution patterns (Fig. 3). The honey bee, Megachile deceptoria Perez and other Megachile species visited throughout the day, while Nomioides variegatus (Oliv.) and Lasioglossum malachurum and L. discum (Smith) visited during the morning hours and Ceratina cyanea visited flowers later in the day.

\subsection{Foraging rate}

Nomioides variegatus females spent the longest time of any forager in staminate Ecballium flowers averaging $32 \pm 42$ s per flower (Tab. II). Ceratina cucurbitina (Rossi) averaged $24 \pm 33 \mathrm{~s}$ per staminate flower but only $3 \pm 3$ s per pistillate flower. Lasioglossum malachurum (11 $\pm 16 \mathrm{~s})$, L. discum $(11 \pm 15 \mathrm{~s})$ and L. villosulum (Kirby) (8 $88 \mathrm{~s}$ ) averaged approximately ten seconds per staminate flower but less than half that in pistillate flowers ( $L$. malachurum $3 \pm 4 \mathrm{~s}, L$. discum $5 \pm 6 \mathrm{~s}$ and $L$. villosulum $1 \pm 0.7 \mathrm{~s}$ ). The honey bee spent an average of only $3 \pm 2$ s per staminate flower and $2 \pm 0.8 \mathrm{~s}$ per pistillate flower. The shortest visitation time was Anthophora quadrifasciata (Villers) with an average of 
Table II. Flower handling times and travel times between flowers of Ecballium elaterium.

\begin{tabular}{|c|c|c|c|c|c|c|}
\hline \multicolumn{3}{|c|}{ Staminate flowers } & \multicolumn{3}{|c|}{ Pistillate flowers } & \multirow{2}{*}{$\begin{array}{c}\text { Proportion } \\
\text { of visits to } \\
\text { female flowers }\end{array}$} \\
\hline $\mathrm{n}$ & handling time (s) & travel time $(\mathrm{s})$ & $\mathrm{n}$ & handling time (s) & travel time $(\mathrm{s})$ & \\
\hline \multicolumn{7}{|c|}{ Lasioglossum discum (Sm.) - 43 individuals, 6 days } \\
\hline 205 & $11.1 \pm 14.7$ & $1.2 \pm 1.2$ & 12 & $5.5 \pm 6.8$ & $1.2 \pm 1.2$ & 0.055 \\
\hline \multicolumn{7}{|c|}{ Lasioglossum malachurum (K.) - 20 individuals, 4 days } \\
\hline 127 & $11.6 \pm 16.0$ & $1.9 \pm 1.6$ & 8 & $3.2 \pm 4.3$ & $1.1 \pm 0.4$ & 0.059 \\
\hline \multicolumn{7}{|c|}{ Lasioglossum villosulum (K.) - 20 individuals, 1 day } \\
\hline 93 & $8.9 \pm 9.0$ & $1.8 \pm 1.7$ & 2 & $1.5 \pm 0.7$ & $3.5 \pm 3.5$ & 0.021 \\
\hline \multicolumn{7}{|c|}{ Nomioides variegatus (Ol.) - 11 individuals, 6 days } \\
\hline 51 & $32.0 \pm 42.4$ & $7.4 \pm 11.7$ & 0 & & & - \\
\hline \multicolumn{7}{|c|}{ Megachile centuncularis (L.) -6 individuals, 2 days } \\
\hline 42 & $1.3 \pm 0.6$ & $1.0 \pm 0.0$ & 3 & $1.0 \pm 0.0$ & $1.0 \pm 0.0$ & 0.066 \\
\hline \multicolumn{7}{|c|}{ Megachile pilidens A. -6 individuals, 1 day } \\
\hline 69 & $1.9 \pm 1.0$ & $1.3 \pm 0.9$ & 0 & & & - \\
\hline \multicolumn{7}{|c|}{ Anthophora quadrifasciata (V.) - 2 individuals, 1 day } \\
\hline 68 & $1.0 \pm 0.0$ & $1.4 \pm 1.0$ & 1 & 1.0 & 1.0 & 0.014 \\
\hline \multicolumn{7}{|c|}{ Ceratina cyanea $(\mathrm{K})-$.4 individuals, 2 days } \\
\hline 58 & $3.2 \pm 2.5$ & $4.9 \pm 9.2$ & 2 & $4.0 \pm 1.4$ & $1.5 \pm 0.7$ & 0.033 \\
\hline \multicolumn{7}{|c|}{ Ceratina cucurbitina (Rossi) - 7 individuals, 1 day } \\
\hline 20 & $23.5 \pm 33.1$ & $6.8 \pm 8.1$ & 3 & $3.6 \pm 3.0$ & $10.6 \pm 13.4$ & 0.13 \\
\hline \multicolumn{7}{|c|}{ Apis mellifera L. -30 individuals, 3 days } \\
\hline 507 & $3.4 \pm 2.3$ & $2.6 \pm 1.8$ & 5 & $2.2 \pm 0.8$ & $3.0 \pm 1.7$ & 0.009 \\
\hline
\end{tabular}

only $1.0 \pm 0.0 \mathrm{~s}$ per staminate and pistillate flowers. For the eight species visiting both staminate and pistillate flowers, there was a significant difference in handling time among species $(\mathrm{F}=6.9$, df $=7,962, P=0.001)$ and between the staminate and pistillate flowers (F $=14.1$, df $=1,962, P=0.001)$. The handling time among species and staminatepistillate interaction was also significant $(\mathrm{F}=$ 2.3 , df $=7,962, P=0.03$ ). The overall mean handling time among the eight species on staminate flowers was $5.8 \pm 12.1 \mathrm{~s}$ and on pistillate flowers $3.7 \pm 5.0 \mathrm{~s}$.

Travel time between Ecballium flowers ranged from $7.4 \pm 11.7$ seconds for Nomioides to approximately one second for Lasioglossum discum and L. malachurum, L. villosulum, Megachile centuncularis, M. pilidens and Anthophora quadrifasciata (Tab. II). For the eight species visiting both flowers, there was a significant difference among species travel time between staminate flowers (no visitation between two pistillate flowers was observed) ( $\mathrm{F}=8.2, \mathrm{df}=7,862, P=0.001)$. The was no travel time difference between pistillate and staminate flowers $(\mathrm{F}=0.11, \mathrm{df}=1,862, P=$ 0.74 ) or the among species travel time and staminate-pistillate flower interaction $(\mathrm{F}=0.97, \mathrm{df}$ $=7,862, P=0.45)$. The overall mean travel time between staminate flowers among the eight species was $2.5 \pm 3.2 \mathrm{~s}$ and from pistillate to staminate flowers was $2.2 \pm 4.2 \mathrm{~s}$.

For the ten species of foragers with timed flower visits, only three species showed a significant relationship between handling time and the time of day. Handling time decreased through the day for the honey bee $(\mathrm{F}=37.6$, $\mathrm{df}=1,-505, P<0.0001 ; \mathrm{y}=14.9-25.9 \mathrm{x})$, for 


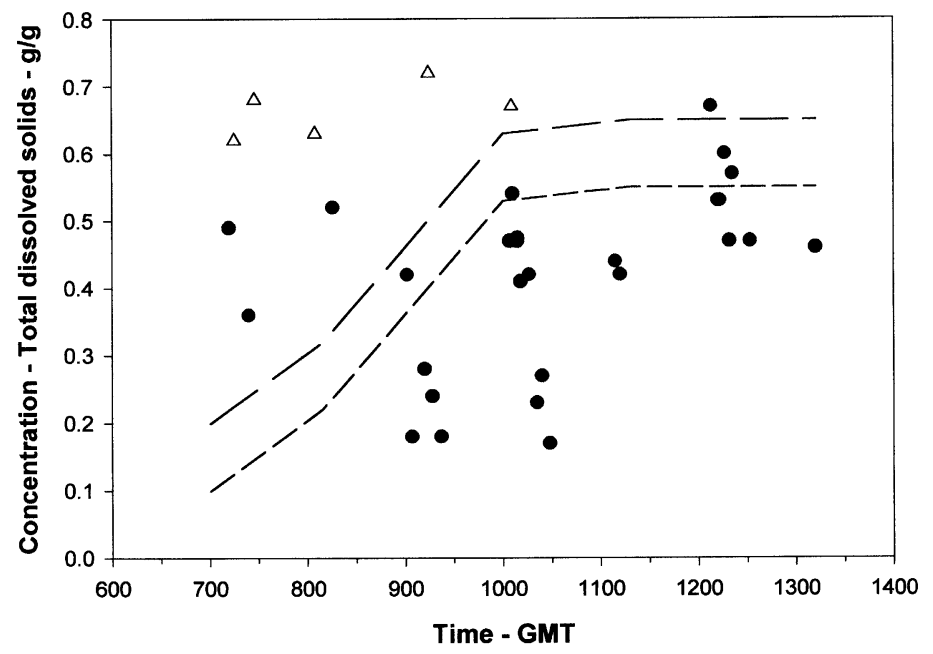

Figure 4. Concentration of nectar plus $0.05 \mathrm{~g} / \mathrm{g}$ (long dashed line) or minus $0.05 \mathrm{~g} / \mathrm{g}$ (small dashed line) from bagged staminate flowers of $E c$ ballium elaterium and of crop contents from the honey bee, Apis mellifera (open triangles), and non-Apis visitors (solid circles) throughout the day, 9 August 1996, at Caumont-sur-Durance, France.
Nomioides variegatus $(\mathrm{F}=7.7, \mathrm{df}=1,-81$, $P=0.007 ; \mathrm{y}=185-358 \mathrm{x})$ and for Lasioglossum discum $(\mathrm{F}=10.7$, $\mathrm{df}=1,205, P=0.001$; $\mathrm{y}=52.2-93.5 \mathrm{x})$.

Of the ten species for which we timed visiting Ecballium flowers, two species visited no pistillate flowers and only $2.8 \%$ of the total timed flower visits $(36$ of 1,276$)$ were to pistillate flowers. Ceratina cucurbitina visited the most pistillate flowers at $13 \%$ and $\mathrm{Meg}$ achile centuncularis, Lasioglossum discum and $L$. malachurum visited about $6 \%$ pistillate flowers (Tab. II). Significantly fewer pistillate flowers were visited both years when compared to the expected average pistillate flowers present in the flower population $\left(\chi^{2}=\right.$ 31.19 , df $=1, P=0.001)$.

\subsection{Nectar utilization by foragers}

On 9 August 1996 at PSL, 67 individuals representing 14 species were sampled for nectar and, on 12 August 1996 at CSD, 66 individuals representing seven species were sampled for nectar. Nine individuals carried no measurable nectar from the PSL sample. In addition to the 67 individuals sampled from PSL, no measurable nectar was obtained from any Nomioides variegatus bees sampled. Twentyfour of the CSD bees contained no measurable nectar. Nectar utilization showed the same usage pattern at both sites with most foragers before 08:00 GMT not carrying or collecting Ecballium nectar (Figs. 4 and 5). All CSD honey bees sampled carried nectar with total dissolved solids well above the maximum recorded in Ecballium staminate flowers. At PSL more than half of the honey bees collected before 08:00 GMT carried nectar higher in total dissolved solids than that produced by Ecballium flowers. The nectar carried by the morning honey bees is most likely honey brought from the hive stores. This pattern changed in the afternoon at PSL with all honey bees collecting and carrying Ecballium nectar (Fig. 5). Other species of interest in nectar foraging were the large bodied Anthophora quadrifasciata, medium (approximately honey bee size) bodied Lasioglossum discum and smallbodied Ceratina cyanea. Anthophora quadrifasciata and $L$. discum individuals showed nectar foraging similar to honey bees, but $C$. cyanea collected Ecballium nectar throughout their foraging day (Fig. 5).

\section{DISCUSSION}

\subsection{Foragers and pollinators}

Ecballium elaterium flowers at both sites attracted a wide diversity of visitors. Most foragers collected both pollen and nectar and are potential pollinators of Ecballium. All of the pollinators are considered polylectic (Westrich, 1989) in their foraging behavior and all showed a strong preference for staminate flowers. However, the presence of Ecballium pollen in 


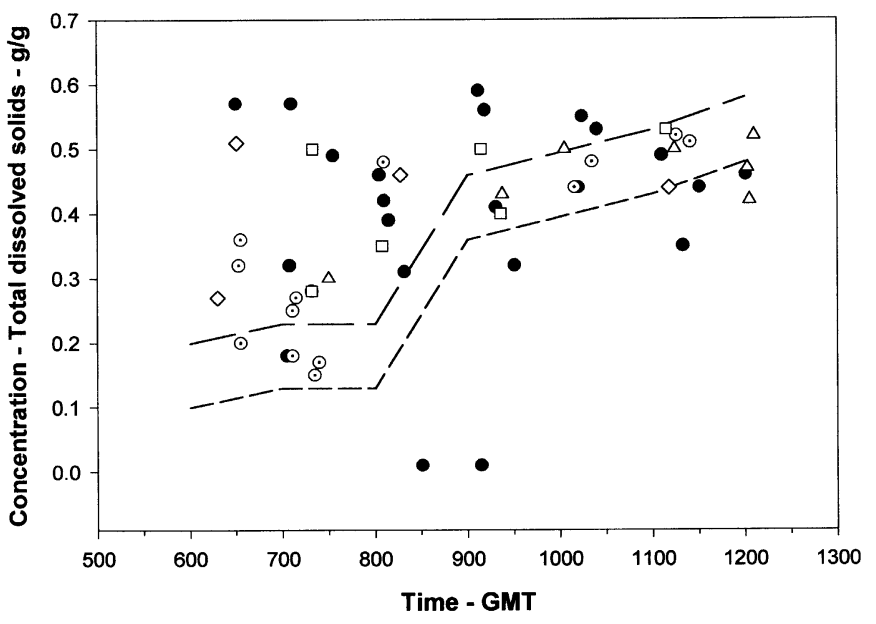

Figure 5. Concentration of nectar plus $0.05 \mathrm{~g} / \mathrm{g}$ (long dashed line) or minus $0.05 \mathrm{~g} / \mathrm{g}$ (small dashed line) from bagged staminate flowers of Ecballium elaterium and of crop contents from the honey bee, Apis mellifera (opendotted circle), Anthophora quadrifasciata (open diamond), Ceratina cyanea (open triangle) and Lasioglossum discum (open square) and from other non-Apis visitors (solid circles) throughout the day, 12 August 1996, at PortSaint-Louis, France. the scopa of Melitta leporina, a known oligoleg on Fabaceae (Westrich, 1989) is most interesting and suggests that Ecballium flowers provide abundant resources, both pollen and nectar, late in the summer and fall. The late summer resource use is supported by honey bees visitation at the PSL. Honey bees did not appear until August and they were traveling $8 \mathrm{~km}$ round trip to obtain nectar and pollen since the only known honey bee hives were located with in the community of PSL. Also, Xylocopa violacea (L.) and Bombus pascuorum (Scop.) were only collected in September at PSL. Both species carried Ecballium pollen. However, it must be pointed out that one of the most common bees observed at PSL, Halictus scabiosae (Rossi), a polylectic species (Westrich, 1989), was rarely collected (only 8 females) at Ecballium flowers and none carried Ecballium pollen.

Although Ecballium elaterium is listed in Knuth's (1908) Handbook of Flower Pollination as requiring pollination, no visitors were listed. Dukas (1987) studied the foraging behavior of bees on Ecballium in Israel and observed that honey bees showed a preference for male over female Ecballium flowers but Lasioglossum politum (Morawitz) and Ceratina mandibularis Friese visited pistillate flowers with nearly equal frequencies as staminate flowers early in the foraging day and that they spent longer time in pistillate flowers. However, over the course of the day these visitation patterns shifted to less frequent and shorter visits to pistillate flowers. Our studies overlap with only one foraging species, the honey bee, and two genera but with different species. For the honey bee, visitation times to staminate and pistillate flowers in our study were not different, whereas Dukas (1987) found staminate flower visits to be nearly twenty times as long ( 0.3 to 6.9 seconds). He found a slightly higher pistillate flower visitation percentage than we measured (5\% to $1 \%$, respectively), and the percentages of total time per flower gender were approximately the same $(99.7 \%$ to $99.3 \%$, respectively to male flowers). At the generic level, very different results were observed for the species. For the genus Lasioglossum, L. politum in Israel spent three times more in staminate flowers than the three Lasioglossum species we observed. For Ceratina, $C$. mandibularis in Israel and $C$. cucurbitina in France showed similar proportions of staminate flower visit, but $C$. cyanea in France showed shorter handling time.

Fahn and Shimony (2001) reported the presence of Hemiptera (possibly Geocoridae or Anthocoridae) in both staminate and pistillate flowers in Israel with about twice as many in staminate flowers. These insects appeared to feed on nectary and neighboring region tissues. These authors also showed the presence of Ecballium pollen on these insects and suggested that they may transfer pollen from staminate to pistillate flowers. We 
recorded the coccinellid beetles, Epilachna chrysomelina, from male flowers and larvae were seen feeding on the pollen and anthers as well as the leaves. These beetles are not considered pollinators. We did not record any Hemiptera adults or nymphs visiting or feeding on Ecballium flower tissues at either study site.

\subsection{Nectar production and forager behavior}

Nectar production in Ecballium elaterium shows both site and regional differences. Nectar production in bagged staminate flowers was different between sites in our study and among the French and Israel locations (Dukas, 1987; Fahn and Shimony, 2001). Bagged staminate flowers in Israel produced 0.9 to $1.0 \mu \mathrm{l} /$ flower, while in France they produced from 0.3 to $0.6 \mu \mathrm{l} /$ flower. The time of nectar production was also different between France and Israel. Israel flowers had 0.7 to $3.0 \mu \mathrm{l} /$ flower by 0600 , while French flowers contained little nectar at that time. The concentration of sugar was regionally different with a higher content in the Israel population (Dukas, 1987). The absence of nectar production in pistillate Ecballium flowers is known in several other species in the genera Monordica, Lagenaria and Luffa (Bahadur et al., 1986). Pistillate flowers in other monoecious species of cucurbits usually produce more nectar than staminate flowers (Cucumis melo L. (Fisher and Pomeroy, 1989), Cucumis sativus L. (Fahn, 1949; Collison and Martin, 1979), Cucurbita pepo L. (Tepedino, 1981; Couto and Calmona, 1993; Nepi and Pacini, 1993; Nepi et al., 1996), Curcurbita maxima (Fahn, 1949) and Bryonia dioica (Jacq.) (Rust and Vaissière, unpublished data)).

The nectar forager data (Figs. 4 and 5) showed that many of the large bodied visitors to Ecballium flowers in the early hours were carrying nectar with sugar concentrations above that being produced in the Ecballium flowers. For the honey bee, early hour visitors were carrying hive honey as flight fuel. But later in the day, flower nectar and forager crop content were similar in sugar concentration. This high sugar concentration of early morning forager crop content may relate to energy demands to fly long distances to collect pollen.
The early flowering staminate flowers of Ecballium present large amounts of pollen. Matinal anthesis with the production of copious amounts of large-size pollen with rich sticky grains is also characteristic of other genera of cucurbits (Bryona, Cucumis, Citrullus, Cucurbita, and Luffa) (Smith, 1977), but there are also nocturnal flowering genera (Monordica, Trichosanthes) (Skinner and Lovett, 1992; Free, 1993). Since most staminate flowers of matinal flowering cucurbits, including Ecballium, last only one day (Adlerz, 1966; Skinner and Lovett, 1992), the pollen reward for foragers is renewed daily. However, Fahn and Shimony (2001) reported that Ecballium flowers stayed open for 4 days on plants produced in a growth chamber.

The daily forager activity patterns (Fig. 3) suggests that certain foragers (Nomioides, Lasioglossum) are after both pollen and less concentrated nectar in the morning hours while others either continue to forage throughout the anthesis period (Apis, Megachile) or forage for nectar with higher concentration of sugar and less for pollen in the afternoon (Ceratina). Chen (1996) showed an almost normal distribution for honey bees visiting cantaloupe with a peak at 10:00. Miura (1982) showed a division of pollinators on Japanese pear, Pyrus serotina, with bees in the morning hours and syrphid flies in the late afternoon.

Ecballium nectar volume and sugar concentration were below the averages found for 76 other Mediterranean shrubland species (mean volume $0.76 \mu \mathrm{l}$ and mean sugar concentration $0.43 \mathrm{~g} / \mathrm{g}$ ) (Petanidou and Smets, 1995). This information combined with the general observation that in matinal flowering cucurbits, the pistillate flowers produce more nectar and receive more forager visitations (Collison and Martin, 1979; Bahadur et al., 1986; Couto et al., 1990; Delesalle and Buchmann, 1991; Nepi and Pacini, 1993; Chen, 1996; Wolf et al., 1999) suggests that pollinators to Ecballium are after pollen and nectar is a secondary reward. This hypothesis is supported by the absence of male bees in our samples. The increase in nectar sugar concentration later in the day and the utilization of this nectar by the foragers (Figs. 5 and 6) indicates that both pollen and nectar are collectable rewards later in the foraging day. However, flower visitation times were significantly shorter later in the 
foraging day for three of the 10 timed species and the other seven showed neither an increase nor decrease in flower visitation time. The bees did not respond to the higher sugar nectar reward offered later in the foraging day with increased visitation time.

The relatively sparse visitation to pistillate flowers and the absence of any pistillate flower reward to foragers is deceit pollination with intersexual mimicry within unisexual flowers of Ecballium (Baker, 1967; Dukas, 1987; Delph, 1996; Schemske et al., 1996). The deceit pollination syndrome is also supported from the forager visitation patterns. We observed that a large number of the pollinators to Ecballium actively chose between staminate and pistillate flowers with pistillate flowers visited less often than their frequency of occurrence in the flower populations. Only Ceratina cucurbitina visitations were approximately proportional to flower distributions ( $13 \%$ to $21 \%$, respectively), but like all 10 timed species, they spent significantly less time in pistillate flowers (3.6 seconds in pistillate to 23.5 in staminate). Deceit pollination by staminate flower mimicry in Ecballium appears to be successful for seed production (Vaissière and Rust, unpublished data) in fruit with a restricted size and seed number due to the explosive dehiscing mechanism of the berry (Tutin et al., 1968). The Ecballium reproductive system can be tested for staminate and pistillate floral trait selection and the phylogenetic relationships by comparing reproductive success between monoecious and dioecious forms of Ecballium elaterium (Costich, 1995). Costich (1995) found that when monoecious and dioecious forms were grown in common gardens, dioecious females produced similar numbers of flowers, but more fruits and seeds, than did the monoecious plants, but the seeds were smaller. Dioecious males always produced more flowers than did the monoecious plants. Unfortunately, Costich did not report pollinator activity in the garden plantings.

\section{ACKNOWLEDGMENT}

We thank M. El-Maâtaoui, UMR 406 Écologie des Invertébrés, Avignon, France with help in the identifications of the local flora; P. Andreas W. Ebmer, Linz, Austria assisted with the identification of Lasioglossum and confirmed that Pseudapis unidentata is new to France; S. Clement, USDA, ARS, Pullman, Washington, J. Thompson, CEFE, CNRS, Montpellier, France and C. Cripps, NDEP, Carson City, Nevada for reviewing the manuscript prior to submission and the journal reviewers for several suggestions that improved the final draft.

Résumé - Biodiversité des pollinisateurs et utilisation des ressources florales d'Ecballium elaterium (Cucurbitaceae), une plante endémique méditerranéenne. Nous avons étudié la biodiversité des pollinisateurs présents sur Ecballium elaterium (L.) A. Richard (Cucurbitaceae) ou concombre d'âne, espèce monotype restreinte au Bassin méditerranéen et qui possède des fleurs pistillées pollinisées uniquement par tromperie puisqu'elles n'offrent ni nectar ni pollen. Les insectes anthophiles ont été récoltés en 1996 et 1997 sur deux sites du sud de la France durant toute la période de floraison. L'un des sites (PSL) est considéré comme un site naturel du delta du Rhône, l'autre (CSD) est situé en bordure d'une décharge. $\mathrm{La}$ densité de fleurs, la production et la concentration du nectar ont été notées. Les butineuses ont été dénombrés toutes les heures sur 100 fleurs staminées et/ou pistillées sur chaque site au cours des périodes d'échantil-lonnage hebdomadaires. Les visiteuses des fleurs staminées et pistillées ont été récoltées tout au long de la journée, la présence de pollen et le contenu de leur jabot ont été examinés. Les insectes ont été conservés pour être ensuite identifiés.

En 1997 peu de pollinisateurs ont été observés à PSL en raison d'une sécheresse ayant provoqué une floraison d'Ecballium réduite et tardive (Fig. 1), tandis que le site CSD a disparu suite à la fermeture de la décharge. Les fleurs pistillées n'ont pas produit de nectar, alors que les staminées ont produit environ $156 \mathrm{mg}$ de sucre/fleur sur les deux sites. Les 852 insectes récoltés sur les fleurs d' $E$. elaterium couvraient six familles, 15 genres et 43 espèces d'abeilles (Hymenoptera, Apoidea). Une coccinelle (Coleoptera, Coccinellidae) et un syrphe (Diptera, Syrphidae) étaient également présents. Seuls 21 specimens ont été récoltés sur les fleurs mâles (Tab. I).

En 1996 la densité moyenne de butineuses pour 100 fleurs était environ de 1,1 individu au cours de toute la période de floraison (Fig. 2). Les butineuses les plus communes présentaient des modes de répartition journalière variables (Fig. 3). L'abeille Megachile deceptoria et d'autres espèces de mégachiles visitaient les fleurs toute la journée, alors que Nomioides variegatus, Lasioglossum malachurum et $L$. discum n'étaient présentes que le matin et $C$. cyanea que plus tard dans la journée.

Les femelles de $N$. variegatus ont passé plus de temps que toute autre butineuse dans les fleurs 
staminées d'Ecballium (32 s en moyenne par fleur, Tab. II). Ceratina cucurbitina a passé environ $24 \mathrm{~s}$ par fleur staminée, mais seulement $3 \mathrm{~s}$ par fleur pistillée. Anthophora quadrifasciata avait la période de visite la plus courte avec en moyenne $1,0 \mathrm{~s}$ seulement par fleur staminée et par fleur pistillée. Pour les huit espèces visitant les deux types de fleurs, il y avait une interaction significative entre le type floral et l'espèce d'abeille sur la durée de la visite et cette durée a varié de façon significative entre les espèces d'une part et entre les fleurs staminées et pistillées d'autre part.

Le nectar a été utilisé selon le même mode sur les deux sites : la plupart des butineuses de nectar ne portaient ni ne récoltaient de nectar avant 0800 GMT (Figs. 4 et 5). Sur les sites CSD et PSL la plupart des abeilles récoltées tôt le matin transportaient du nectar dont la concentration en solides totaux dissous était plus élevée que celle du nectar d'Ecballium. L'après-midi ce mode d'utilisation changeait à PSL : toutes les abeilles domestiques récoltaient et portaient du nectar d'Ecballium (Fig. 5). Les autres espèces impliquées dans la récolte de nectar étaient les grosses anthophores $A$. quadrifasciata, les abeilles Lasioglossum discum de taille moyenne (environ la taille d'une abeille domestique) et les petites $C$. cyanea. Les individus d'A. quadrifasciata et de L. discum avaient des horaires de butinage du nectar semblables à ceux des abeilles domestiques, mais $C$. cyanea récoltait le nectar tout au long de la journée (Fig. 5).

\section{pollinisation par tromperie / Apoidea / nectar /} pollen / Ecballium elaterium

\section{Zusammenfassung - Biodiversität der Bestäu- ber und Nutzung der Blüte der am Mittelmeer endemischen Ecballium elaterium (Cucurbita- ceae). Wir untersuchten die Biodiversität der Insek- tenarten, die als potentielle Bestäuber von Ecbal- lium elaterium (L.) A. Richard (Cucurbitaceae) in Frage kommen. E. elaterium ist eine monotypische Art, die auf das mediterrane Becken begrenzt ist. Sie hat männliche Blüten und eine Bestäubung erfolgt nur durch Täuschung der Insekten, da sie weder Nektar noch Pollen anbietet.}

Zwei Jahre lang, 1996 und 1997, wurden Insekten während der Hauptblütezeit an zwei Lokalitäten in Südfrankreich gesammelt. Die eine im Flussdelta der Rhone gelegene Gegend (PSL) wurde als naturbelassene Landschaft angesehen, während der andere Ort (CSD) in einem genutzten Areal lag. Blütendichte, Produktion und Konzentration des Nektars wurde bestimmt. Während der wöchentlichen Probenahmen wurden an beiden Probeorten sammelnde Insekten stündlich an 100 männlichen und/oder weiblichen Blüten per Population gefangen. Besucher von beiden, von weiblichen und männlichen Blüten, wurden während des ganzen Tages gesammelt und für eine Identifikation aufbewahrt. Weiterhin wurde die Zusammensetzung des gesammelten Pollens bestimmt.

Aufgrund großer Trockenheit, die eine spätere und geringere Blüte von E. elaterium verursachte, wurden 1997 im PSL Gebiet nur wenige Besucher festgestellt (Abb. 1). Die CSD Gegend war durch die Bearbeitung des Bodens zerstört. Männliche Blüten erzeugten keinen Nektar, weibliche Blüten dagegen hatten an beiden Standorten im Mittel $156 \mathrm{mg}$ Zucker pro Blüte.

Insgesamt wurden an den Blüten von E. elaterium 852 Individuen aus sechs Familien, 15 Gattungen und 43 Arten von Bienen (Hymenoptera, Apoidea) gesammelt. Ein Marienkäfer (Coleoptera, Coccinellidae) und eine Schwebfliege (Diptera, Syrphidae) wurden ebenfalls als Blütenbesucher festgestellt. Bei 33 Bienenarten fand sich Pollen von E. elaterium in den Transporteinrichtungen und sie wurden entsprechend als Bestäuber definiert.

Im Jahr 1996 betrug während der gesamten Blütezeit die durchschnittliche Zahl an Blütenbesuchen pro Stunde 1,1 Bienen je 100 Blüten (Abb. 2). Die meisten Besucher waren Weibchen, die in der Regel sowohl Pollen sammelten als auch Nektar saugten, es gab nur 21 Männchen (Tab. I). Die zahlenmäßig dominanten Arten waren Lasioglossum malachurum (Kirby), die Honigbiene (Apis mellifera) und Ceratina cyanea (Kirby). Für diese Arten wurden die jährlichen, jahreszeitlichen und täglichen Aktivitätsmuster (Abb. 3) sowie das Verhalten in Bezug auf Pollensammeln und Nektaraufnahme dargestellt. Honigbienen, Megachile deceptoria und andere Megachile Arten sammelten den ganzen Tag, Nomioides variegatus, Lasioglossum malachurum und L. discum kamen nur in den Morgenstunden und Ceratina cyanea erst am Nachmittag.

Nomioides variegatus Weibchen verbrachten von allen Sammlern die längste Zeit in weiblichen Blüten, im Mittel $32 \mathrm{sec}$ pro Blüte (Tab. II). Ceratina cucurbitina blieb durchschnittlich $24 \mathrm{sec}$ auf weiblichen, aber nur $3 \mathrm{sec}$ auf männlichen Blüten. Die kürzeste Besuchszeit hatte Anthophora quadrifasciata mit durchschnittlich $1.0 \mathrm{sec}$ auf weiblichen und männlichen Blüten. Bei den 8 Arten, die weibliche und männliche Blüten besuchten, war die Interaktion der Verweildauer zwischen den Arten und Blütentypen signifikant und es gab signifikante Unterschiede in der Verweildauer zwischen Arten und weiblichen und männlichen Blüten. Die Mehrzahl der Besuche erstreckte sich auf männliche Blüten, während weibliche Blüten weniger als $3 \%$ der Gesamtbesuche erhielten.

Die Nektaraufnahme wies in beiden Gebieten das gleiche Aktivitätsmuster auf, nicht Nektar aufnehmende Besucher erschienen vor 0800 GMT (Abb. 4 
und 5). Bei CSD und PSL enthielten die meisten der gesammelten Honigbienen Nektar, deren gelöste feste Anteile insgesamt einen höheren Wert aufwies als der von E. elaterium Blüten. Dieses Muster änderte sich am Nachmittag in PSL, dann sammelten alle Honigbienen E. elaterium Nektar (Abb. 5). Andere große Bienen wie Anthophora quadrifasciata traten vor allem bei der Nektaraufnahme in Erscheinung. Bienen mittlerer Größe (etwa so groß wie Honigbienen) wie Lasioglossum discum und die kleinen Ceratina cyanea waren auch von Interesse. Die Bienen A. quadrifasciata und $L$. discum wiesen ein ähnliches Sammelverhalten auf wie die Honigbienen, aber $C$. cyanea sammelte Nektar während des ganzen Tages (Abb. 5).

\section{Bestäubung / Bienen / Nektar / Pollen / Sammelerfolg / Pollentäuschung / Ecballium elaterium}

\section{REFERENCES}

Adlerz W.F. (1966) Honey bee visit numbers and watermelon pollination, J. Econ. Entomol. 59, 28-30.

Affre L., Thompson J.D. (1997) Population genetic structure and levels of inbreeding depression in the Mediterranean island endemic Cyclamen creticum (Primulaceae), Biol. J. Linn. Soc. 60, 527-549.

Allen W.G., Peter B., Bitner R., Burquezs A., Buchmann S.L., Cane J., Cox P.A., Dalton V., Feinsinger P., Ingram M., Inouye D., Jones E.E, Kennedy K., Kevan P., Koopowitz H., Medellin R., Medellin M.S., Nabhan G.P. (1998) The potential consequences of pollinator declines on the conservation of biodiversity and stability of food crop yields, Conserv. Biol. 12, 8-17.

Bahadur B., Chaturvedi A., Swamy N.R. (1986) Floral nectarines in some Cucurbitaceae, J. Swamy Bot. Club 3, 149-156.

Baker H.G. (1967) "Mistake" pollination as a reproductive system with special reference to the Caricaceae, in: Burley J., Styles B.T. (Eds.), Tropical trees: Variation, breeding and conservation, Academic Press, New York, pp. 161-169.

Ben Y.D., Gal D., Chen M., Rosen D. (1996) Potential of Aspongopus viduatus F. (Heteroptera: Pentatomidae) as a biocontrol agent for squirting cucumber, Ecballium elaterium (L.) A. Rich (Cucurbitaceae), Biol. Contr. 7, 48-52.

Bosch J. (1992) Floral biology and pollinators of three co-occurring Cistus spp. (Cistaceae), Bot. J. Linn. Soc. 109, 39-55.

Buchmann S.L., Nabham G.P. (1996) The forgotten pollinators, Island Press, Washington, DC.

Chen C.T. (1996) Effects of honey bees on pollination and fruit set of cantaloupe, Chinese J. Entomol. 16, 25-33 (in Chinese with English abstract).
Collison C.H., Martin E.C. (1979) Behavior of honeybees (Apis mellifera) foraging on male and female flowers of Cucumis sativus, J. Apic. Res.18, 184-190.

Council for Agriculture Science and Technology (1999) Benefits of biodiversity, Coun. Agr. Sci. Tech. Task Force Report 0, 1-133.

Costich D.E. (1995) Gender specialization across a climatic gradient: Experimental comparison of monoecious and dioecious Ecballium, Ecology 76, 1036-1050.

Costich D.E., Meagher T.R. (1992) Genetic variation in Ecballium elaterium (Cucurbitaceae): Breeding system and geographic distribution, J. Evol. Biol. 5, 589-601.

Couto R.H.N., Calmona R.C. (1993) Entomophilous pollination in cucumber (Cucumis sativus L. var. Aodai Melhorada), Naturalia (Rio Claro) 18, $77-$ 82 (in Portuguese with English abstract).

Couto R.H.N., Pereira J.M.S., Couto L.A. (1990) Effects of pollination in Cucurbita pepo (summer squash), Cientifica 18, 21-28 (in Portuguese with English abstract).

Cruden R.W., Hermann S.M. (1983) Studying nectar: Some observations on the art, in: Bentley B., Elias T. (Eds.), The biology of nectaries, Columbia University Press, New York, pp. 223-242.

Dafni A., Bernhardt P., Shimida A., Ivri Y., Greenbaum S., O’Toole C., Losito L. (1990) Red bowl-shaped flowers: Convergence for beetle pollination in the Mediterranean region, Isr. J. Bot. Basic Appl. Plant Sci. 39, 81-92.

Delph L.F. (1996) Flower size dimorphism in plants with unisexual flowers, in: Lloyd D.G., Barrett S.C.H. (Eds.), Floral biology, Chapman \& Hall, New York, pp. 217-237.

Dukas R. (1987) Foraging behavior of three bee species in a natural mimicry system: Female flowers which mimic male flowers in Ecballium elaterium (Cucurbitaceae), Oecologia 74, 256263.

Delesalle V.A., Buchmann S.L. (1991) Outcrossing hypothesis and weal preference for pistillate flowers in the monoecious cucurbit, Apodanthera undulata, Evol. Trends Plants 5, 37-41.

Fahn A., Shimony C. (2001) Nectary structure and ultrastructure of unisexual flowers of Ecballium elaterium (L.) A. Rich. (Cucurbitaceae) and their presumptive pollinators, Ann. Bot. 87, 27-33.

Fisher R.M., Pomeroy N. (1989) Pollination of greenhouse muskmelons by bumble bees (Hymenoptera: Apidae), J. Econ. Entomol. 82, 1061-1066.

Frankie G.W., Vinson S.B., Rizzardi M.A., Griswold T., O’Keefe S., Snelling R.R. (1997) Diversity and abundance of bees visiting a mass flowering tree species in disturbed seasonal dry forest, Costa Rica, J. Kans. Entomol. Soc. 70, 281-296.

Free J.B. (1993) Insect pollination of crops, Academic Press, New York.

Harant H., Jarry D. (1963) Guide du Naturaliste dans le Midi de la France, Delachaux et Niestlé, Grunelle, Paris. 
Herrera C.M. (1987) Components of pollinator "quality": Comparative analysis of a diverse insect assemblage, Oikos 50, 79-90.

Herrera C.M. (1988) Variation in mutualisms: The spatio-temporal mosaic of a pollinator assemblage, Biol. J. Linn. Soc. 35, 95-125.

Herrera C.M. (1989) Pollinator abundance, morphology, and flower visitation rate: Analysis of the "quantity" component in a plant-pollinator system, Oecologia 80, 241-248.

Herrera C.M. (1992) Historical effects and sorting processes as explanations for contemporary ecological patterns: Character syndromes in Mediterranean woody plants, Am. Nat. 140, 421446.

Herrera C.M. (1993) Selection of floral morphology and environmental determinants of fecundity in a hawk moth-pollinated violet, Ecol. Monogr. 63, 251-275.

Herrera C.M. (1996) Floral traits and plant adaptation to insect pollinators, in: Lloyd D.G., Barrett C.H. (Eds.), Floral biology, Chapman \& Hall, New York.

Herrera J. (1988) Pollination relationships in southern Spanish Mediterranean shrublands, J. Ecol. 76, 274-287.

Jodral M.M., Jimenez J.M., Ahmad A.M., Navarro M.M.C., Cabo C.P. (1990) Ecballium elaterium (L.) A. Richard: II. Morphological and phytochemical studies, Boil. Soc. Brotherina 63, 213-224 (in Spanish with English abstract).

Kevan P.G. (1999) Pollinators as bioindicators of the state of the environment: Species, activity and diversity, Agric. Ecosyst. Environ. 74, 373-393.

Kevan P.G., Creco C.F., Belaoussoff S. (1997) Lognormality of biodiversity and abundance in diagnosis and measuring of ecosystemic health: Pesticide stress on pollinators on blueberry heaths, J. Appl. Ecol. 34, 1122-1136.

Knuth P. (1908) Handbook of flower pollination, Oxford Clarendon Press, Oxford.

Martin P. (1997) La Nature Méditerranéenne en France, Delachaux et Niestlé, Paris.

McLean R.C., Ivimey-Cook W.R. (1956) Textbook of theoretical botany, Longmans, Green and Co. New York.

Miura T. (1982) The hourly change of pollinator association found in the Japanese pear (Pyrus serotina) cultivar Nijisseili orchard during daytime, Bull. Fac. Agric. Shimane Univ. 16, 159-165.

Molinier R., Devaux J.P. (1978) Carte phytosociologique de la Camargue au 1/50,000, Biologie et écologie méditerranéenne, Ann. Univ. Provence, 5, 159 .

Nepi M., Pacini E. (1993) Pollination, pollen viability and pistil receptivity in Cucurbita pepo, Ann. Bot. (London) 72, 527-536.

Nepi M., Pacini E., Willemse M.T.M. (1996) Nectary biology of Cucurbita pepo: ecophysiological aspects, Acta Bot. Neerl. 45, 41-54.
Pascual-Villalobos M.J., Robledo A. (1999) Antiinsect activity of plant extracts from the wild flora in southeastern Spain, Biochem. Syst. Ecol. 27, $1-10$.

Petanidou T., Vokou D. (1990) Pollination and pollen energetics in Mediterranean ecosystems, Am. J. Bot. 77, 986-992.

Petanidou T., Smets E. (1995) The potential of marginal lands for bees and apiculture: Nectar secretion in Mediterranean shrublands, Apidologie 26, 39-52.

Potts-Sinon G., Dafni A., Ne'eman G. (2001) Pollination of a core flowering shrub species in Mediterranean phrygana: Variation in pollinator diversity, abundance and effectiveness in response to fire, Oikos 92, 71-80.

Schaffer W.M., Schaffer M.V. (1979) The adaptive significance of variations in reproductive habit in the Agavaceae. II. Pollinator foraging behavior and selection for increased reproductive expenditure, Ecology 60, 1051-1069.

Schaffer W.M., Zeh D.W., Buchmann S.L., Kleinhans S., Schaffer M.V., Antrim J. (1983) Competition for nectar between introduced honey bees and native North American bees and ants, Ecology 64, 564-577.

Schemske D.W., Ågren J., LeCorff J. (1996) Deceit pollination in the monoecious, neotropical herb Begonia oaxacana (Begoniaceae), in: Lloyd D.G., Barrett S.C.H. (Eds.), Floral biology, Chapman \& Hall, New York, pp. 292-318.

Skinner J.A., Lovett G. (1992) Is one visit enough? Squash pollination in Tennessee, Am. Bee J. 132, 815.

Smith J.P. (1977) Vascular plant families, Mad River Press, Eureka, California.

Sokal R.R., Rohlf F.J. (1995) Biometry, W.H. Freeman, San Francisco.

Talavera S., Bastida F., Ortiz P.L., Arista M. (2001) Pollinator attendence and reproductive success in Cistus libanotis L. (Cistaceae), Int. J. Plant Sci. $162,343-352$.

Tepedino V.J. (1981) The pollination efficiency of the squash bee (Peponapis prunosa) and the honey bee (Apis mellifera) on summer squash (Cucurbita pepo), J. Kans. Entomol. Soc. 54, 359-377.

Tutin T.G., Heywood V.H., Burges N.A., Moore D.M., Valentine D.H., Waters S.M., Webb D.A. (1968) Flora Europaea, Volume 2 Rosaceae to Umbelliferae, Cambridge University Press, Cambridge.

Vaissière B.E., Malabœuf F., Rodet G. (1996) Viability of cantaloupe pollen carried by honeybees, Apis mellifera, varies with foraging behavior, Naturwissenschaften 83, 84-86.

Westrich P. (1989) Die Wildbienen BadenWuerttembergs, Volume 1 and 2, Eugen Ulmer, Stuttgart.

Wolf S., Lensky Y., Paldi N. (1999) Genetic variability in flower attractiveness to honeybees (Apis mellifera L.) within the genus Citrullus, Hortscience 34, 860-863. 